\title{
Use of Zero Water Discharge Technology through the Application of Nitrifying Bacteria and Textile Vertical Substrate in Grow-Out Phase of Macrobrachium rosenbergii De Man
}

Gede Suantika*, Dea Indriani Astuti, Rifki R Arief, Malendra Rusni and Osman R Turendro

Microbial Biotechnology Research Group, School of Life Sciences and Technology, Institut Teknologi Bandung, Jl. Ganesha 10, Bandung, Indonesia

\begin{abstract}
This study was conducted to develop a zero water discharge technology for Macrobrachium rosenbergii growth in order to solve the unpredictability of prawn production during grow-out phase. The system consists of three major compartments: (1) Prawn culture tank, (2) Trickling biofilter for nitrification process, and (3) Textile vertical substrate for prawn territory expansion. The trial was conducted in three diferent stages: (1) nitrifying bacteria of $10^{5}$ Colony Forming Units. $\mathrm{mL}^{-1}\left(\mathrm{CFU} \cdot \mathrm{mL}^{-1}\right)$ was inoculated into the culture 24 hours prior to juvenile stocking and every 10 days during culture period, (2) the culture was grouped into five treatments: 30 individuals. $\mathrm{m}^{2}$ (control), 40 individuals. $\mathrm{m}^{2}$, 50 individuals. $\mathrm{m}^{2}, 60$ individuals. $\mathrm{m}^{2}$, and 70 individuals. $\mathrm{m}^{2}$, and (3) measurements of biological, physicochemical, and microbiological culture parameters. Optimum culture performance was obtained in the culture with initia stocking density of 30 individuals. $\mathrm{m}^{-2}$ (control) with final metabolic body weight, length, specific growth rate (SGR), survival rate $(\mathrm{SR})$, feed conversion rate $(\mathrm{FCR})$ of $(11.37 \pm 4.92) \mathrm{g},(10.69 \pm 1.45) \mathrm{cm}, 2.569 \%$. day ${ }^{-1}, 78.3 \%$, and 0.99 , respectively. However, from an economic perspective, stocking with 70 individuals. $\mathrm{m}^{-2}$ (treatment IV) produced the highest total final biomass $(975 \mathrm{~g})$ and highest profit (Rp. 19.285 per $\mathrm{kg}$ ) compared to the other treatments. Results indicate that use of the developed zero-water discharge rearing system with the application of nitrifying bacteria and textile vertical substrate can maintain good water quality to support a higher stocking density, better growth and larval survival rate and profit of prawn M. rosenbergii de Man grow-out culture.
\end{abstract}

Keywords: M. rosenbergii; Nitrifying bacteria; Grow out; Biofiltration; Zero-water discharge technology; Textile vertical substrate

\section{Introduction}

Indonesia is the fourth most populous country in the world, with a population of nearly 238 million people in 2010 . This number continues to increase by $1.5 \%$ annually, thereby indicating rising demand for protein. During the last four decades, world aquaculture production has increased from 2.5 million metric tons in 1970 to 52.5 million metric tons in 2008, and in recent years, modern aquaculture has contributed up to $40 \%$ of the total aquatic production in the world [1]. On the other hand, capture fisheries production reached a peak of 90 million metric tons in 1989 and has gradually declined afterwards [2]. The above trends and figures clearly indicate the tremendous opportunity for aquaculture to fill the growing demand for fishery products.

Crustacean production is considered an important part of aquaculture, contributing up to $9.5 \%$ of total world production [1]. Marine black tiger shrimp (Penaeus monodon), pacific white shrimp (Litopenaeus vannamei), and giant freshwater prawn (Macrobrachium rosenbergii de Man) are several crustacean aquaculture commodities with high economic value worldwide. In 2008, crustacean aquaculture production contributed to nearly $62.5 \%$ of the total world crustacean production [1].

In Indonesia, giant freshwater prawn (Macrobrachium rosenbergii de Man) can be considered as one of the main farmed freshwater crustacean species having high economic value, with total production of close to 989 metric tons in 2007 [3]. In Asian countries, particulary in Indonesia, almost all farming of $M$. rosenbergii prawns are conducted in farms using extensive earthen ponds. Consequently, the environmental conditions for farming are very poor; most farms have poor water quality, disease concerns, and problems with predation pressure $[3,4]$. Subsequently, the yield of prawns under these culture conditions is generally low and unpredictable. This unpredictability can be attributed to the performance of static culture systems, where the control of water quality becomes a major problem affecting the productivity of prawn culture, especially due to the accumulation of toxic waste substances such as ammonia and nitrite. Another complicating factor is the cannibalistic behaviour that emerges when prawns are cultured at high densities. Nevertheless, due to its simplicity and reliability, the static culture system is still widely used in prawn hatcheries across Asian countries, including Indonesia.

One solution to the high unpredictability and associated problems in prawn grow-out is the development of a production unit that could enable the system to maintain good water quality and allow optimum prawn stocking density, survival and growth rate. In a study by Noerdjito and Suantika [5], it was found that productivity of the static culture system could be improved through manipulation of the nutrient cycle, specifically nitrogen, i.e., by reducing the accumulation of toxic substances such as ammonium and nitrite in the culture through the application of nitrifying bacteria. Reducing cannibalism behaviour of prawn in the culture also becomes a critical action during grow-out period. The objectives of this study was to test the effectiveness of a zero-water discharge rearing system, added with nitrifying bacteria and textile vertical substrate, in increasing the quantity and quality of prawn production. In addition, a simple economic analysis was conducted in

*Corresponding author: Gede Suantika, Microbial Biotechnology Research Group, School of Life Sciences and Technology, Institut Teknologi Bandung, JI. Ganesha 10, Bandung 40132, Indonesia, Tel: +62-22-251-1575, E-mail: gsuantika@sith.itb.ac.id

Received May 02, 2012; Accepted June 27, 2012; Published June 02, 2012

Citation: Suantika G, Astuti DI, Arief RR, Rusni M, Turendro OR (2012) Use of Zero Water Discharge Technology through the Application of Nitrifying Bacteria and Textile Vertical Substrate in Grow-Out Phase of Macrobrachium rosenbergii De Man. J Aquacult Res Dev 3:139 doi:10.4172/2155-9546.1000139

Copyright: (c) 2012 Suantika G, et al. This is an open-access article distributed under the terms of the Creative Commons Attribution License, which permits unrestricted use, distribution, and reproduction in any medium, provided the original author and source are credited. 
Citation: Suantika G, Astuti DI, Arief RR, Rusni M, Turendro OR (2012) Use of Zero Water Discharge Technology through the Application of Nitrifying Bacteria and Textile Vertical Substrate in Grow-Out Phase of Macrobrachium rosenbergii De Man. J Aquacult Res Dev 3:139 doi:10.4172/2155-9546.1000139

Page 2 of 6

order to give some insight into the efficiency of the system in increasing farmer and industrial profit.

\section{Material and Methods}

\section{Experimental design}

A zero water discharge system was developed with the application of nitrifying bacteria as a nitrification bioagent and textile substrate $(1$ $\left.\mathrm{x} 1 \mathrm{~m}^{2}\right)$ to harvest prawn. Prawn was stocked into each pond $\left(2 \times 1 \mathrm{~m}^{2}\right)$ at five different densities, i.e., 30 ind. $\mathrm{m}^{-2}$ (control), 40 ind. $\mathrm{m}^{-2}$ (treatment I), 50 ind. $\mathrm{m}^{-2}$ (treatment II), 60 ind. $\mathrm{m}^{-2}$ (treatment III), and 70 ind. $\mathrm{m}^{-2}$ (treatment IV). 30 ind. $\mathrm{m}^{-2}$ for control was aquired from the previous study conducted by Suantika et al. [6], where the stocking density gives better culture performance compared to static system stocking densities of 10 ind. $\mathrm{m}^{-2}$ adapted from local farmer rearing system.

A measure of $10 \%(\mathrm{v} / \mathrm{v})$ nitrifying bacteria suspension $\left(10^{5} \mathrm{CFU} /\right.$ $\mathrm{mL}$ ) was inoculated into each pond 24 hours prior to prawn stocking. Addition of nitrifying bacteria was conducted every 10 days during the culture period (60 days). Rearing conditions used through out the experiment period were based on the zero water discharge system as shown in figure $1[6]$.

Before running the trial, the system was conditioned for one week to make sure that its capacity, especially the nitrification process in the biofilter reactor, has worked accordingly. Conditioning was conducted by adding $0.001 \%(\mathrm{v} / \mathrm{v}) \mathrm{NH}_{4} \mathrm{Cl}$ daily during one week into the rearing system. The ammonium breaking down capacity of the biofilter was recorded until the system could remove ammonium levels to the lowest level of 0 ppm daily.

\section{Prawn rearing method}

Prawn juveniles used in this study were initially cultured in a hatchery in Sukamandi (West Java, Indonesia) and further acclimatized and cultured in the Laboratory of Aquatic Ecosystem Analysis, School of Life Sciences and Technology, Institut Teknologi Bandung (SITHITB), Indonesia. Mean initial individual weight of juveniles measured $(7.60 \pm 4.21) \mathrm{g}$, while mean initial individual length measured $(9.07 \pm$ $1.55) \mathrm{cm}$. Acclimatization was done for two days in a $2000 \mathrm{~L}$ circular tank with a density of 50 ind. $\mathrm{m}^{-2}$.

During the experiment, prawn juveniles were cultured under the following conditions: aeration rate was kept constant at $200 \mathrm{~mL} \cdot \mathrm{min}^{-1}$ and temperature was maintained stable at $(25 \pm 1){ }^{\circ} \mathrm{C}$. The culture was fed with $5 \%$ commercial diet (water content $12 \%$, crude fat $4 \%$, crude

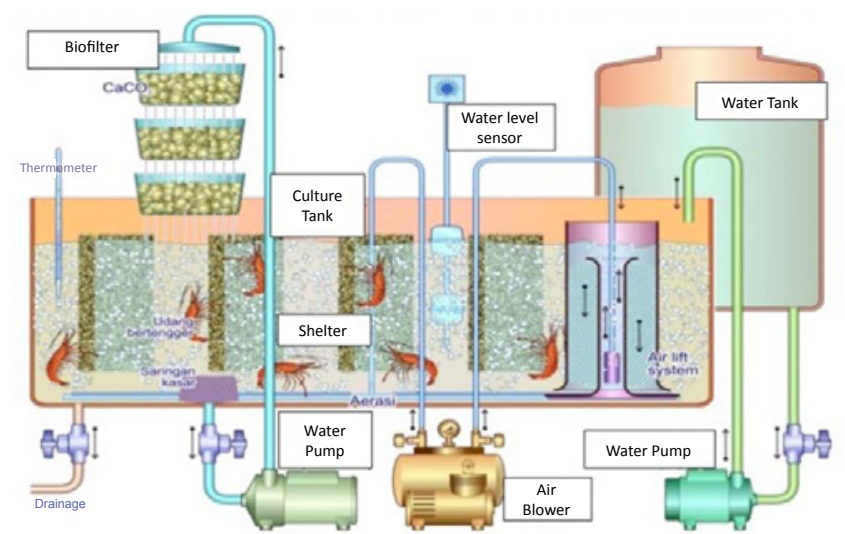

Figure 1: Scheme of biofiltration technology applied in up-scaled zero-water discharge technology culture system for prawn production [6].

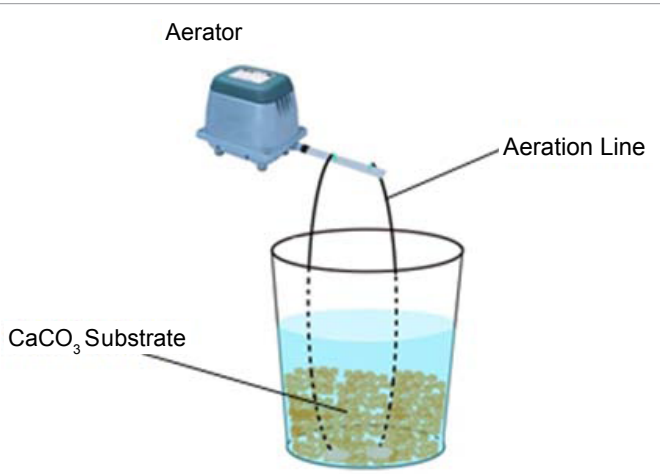

Figure 2: The Bioreactor used for upscaling the nitrifying bacteria.

protein $30 \%$, and crude fiber 6\%) per total prawn weight [7]. Feed was delivered manually three times a day at $09.00 \mathrm{am}, 12.00 \mathrm{pm}$, and $04.00 \mathrm{pm}$. The amount of feed was adapted to the bodyweight sampling results conducted every 10 days of the culture period.

\section{Culture of nitrifying bacteria}

Nitrifying bacteria culture used in this study was obtained from the Laboratory of Microbiology SITH-ITB and was further up-scaled at the Laboratory of Aquatic Ecosystem Analysis. Nitrifying bacteria culture was scaled up in a bioreactor as illustrated in figure 2 .

\section{Water quality parameter}

Several water quality parameters, i.e., ammonium, nitrite, and nitrate concentrations were measured every two days, while $\mathrm{pH}$ level, temperature, and dissolved oxygen were measured daily. Ammonium, nitrate and nitrite concentrations were measured using a $\mathrm{HACH}$ Spectrophotometer by following the Nessler-, Diazotation-, and Nitrate $\mathrm{HCl}$ method at the wavelengths of 425, 371 and 275 and $220 \mathrm{~nm}$, respectively.

Temperature and Dissolved Oxygen (DO) levels were measured using a calibrated DO meter YSI Type 51B, while $\mathrm{pH}$ levels were measured using an OAKTON waterproof Type PC10 pH meter. Nitrifying bacteria cell density was measured daily using Total Bacteria Count method as described by Cappucino and Sherman [8].

\section{Zootechnical parameters}

Mean individual body weight of prawn juveniles was recorded for $50 \%$ of the population in all treatments every 10 days during the culture period (60 days). At the end of the experiment, final juvenile growth (body weight and length), specific growth rate and survival rate were determined. For each treatment, final survival rate was calculated by counting the number of remaining larvae as compared to the initial stock number.

Growth, length, survival rate, and biomass were measured at the beginning (day 0) and at the end of the culture period (day 60). Measurements were conducted on all stocked and harvested juveniles. Juvenile growth was calculated by using the following equation:

$\operatorname{SGR}(\%$ day $)=\left[\operatorname{Ln}\left(\mathrm{W}_{2} / \mathrm{W}_{1}\right) /\left(\mathrm{T}_{2}-\mathrm{T}_{1}\right) \times 100\right]$

Where:

SGR = specific growth rate

$\mathrm{W}_{1}$ = initial live body weight $(\mathrm{g})$ at time $\mathrm{T}_{1}$ (day) 
Citation: Suantika G, Astuti DI, Arief RR, Rusni M, Turendro OR (2012) Use of Zero Water Discharge Technology through the Application of Nitrifying Bacteria and Textile Vertical Substrate in Grow-Out Phase of Macrobrachium rosenbergii De Man. J Aquacult Res Dev 3:139 doi:10.4172/2155-9546.1000139

Page 3 of 6

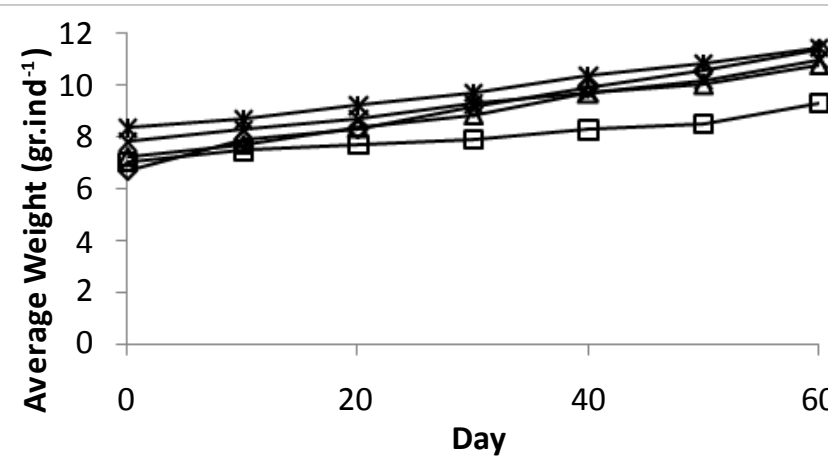

$\neg 30$ ind.m-2 $\multimap-40$ ind.m-2 $\triangle 50$ ind.m-2

$\rightarrow-60$ ind. $m-2 \rightarrow-70$ ind. $m-2$

Figure 3: Prawn mean bodyweight obtained at five different stocking densities during 60 days culture period.

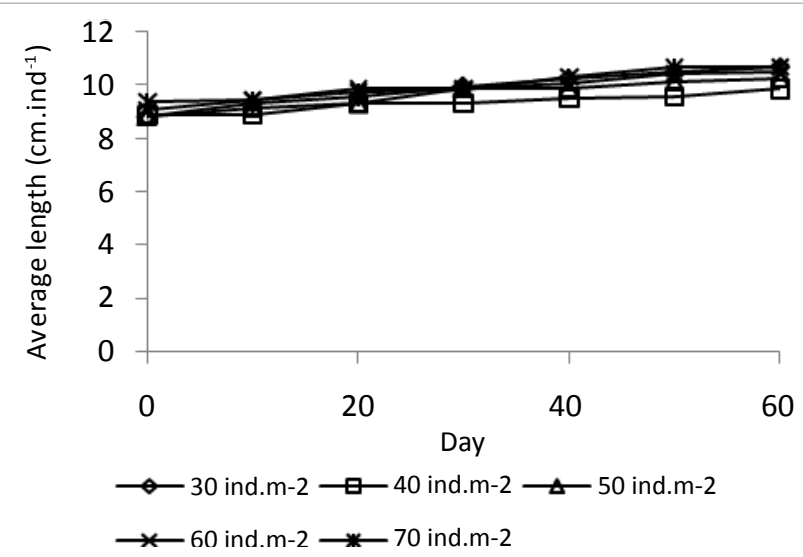

Figure 4: Prawn mean body length obtained at five different stocking densities during 60 days culture period.

$\mathrm{W}_{2}$ = final live body weight $(\mathrm{g})$ at time $\mathrm{T}_{2}$ (day)

The survival rate of juveniles during the trial was calculated by using the following equation:

$\mathrm{SR}=\mathrm{Nt} / \mathrm{No} \times 100 \%$

Where:

$\mathrm{SR}=$ survival rate

No = initial number (quantity) of individuals

$\mathrm{Nt}=$ final number of individuals

\section{Economic feasibility}

Economic feasibility was calculated based on the culture performance parameters including growth, SR, total biomass, Feed Conversion Ratio (FCR), feed cost, and seed cost. Calculations provide insight into the feasibility and profit of culturing prawns at different stocking densities using the zero water discharge rearing technology.

\section{Results and Discussion}

\section{Giant freshwater prawn biomass, growth and survival rate}

Growth of freshwater prawn was determined by measuring individual body length and bodyweight every 10 days during the 60 day cul-

\begin{tabular}{|c|c|}
\hline Stocking density (individuals. $\mathrm{m}^{-2}$ ) & SGR $\left(\%\right.$. day $^{-1}$ ) \\
\hline 30 & 2.569 \\
\hline 40 & 1.393 \\
\hline 50 & 2.105 \\
\hline 60 & 1.916 \\
\hline 70 & 1.893 \\
\hline
\end{tabular}

Table 1: Specific growth rate obtained at five different stocking densities during 60 days culture period.

\begin{tabular}{|c|c|}
\hline Stocking density (individuals. $\mathrm{m}^{-2}$ ) & Survival Rate (\%) \\
\hline 30 & 78.3 \\
\hline 40 & 76.3 \\
\hline 50 & 70.0 \\
\hline 60 & 70.0 \\
\hline 70 & 67.1 \\
\hline
\end{tabular}

Table 2: Prawn survival rate obtained at five different stocking densities during 60 days culture period.

ture period. In general, mean individual body weight and length increased with time in all treatments (Figure 3 ). The highest mean individual bodyweight was recorded in the rearing pond with 70 individuals. $\mathrm{m}^{-2}$, measuring (11.46 \pm 4.52$) \mathrm{g}$ after 60 days of culture, followed by 30 individuals. $\mathrm{m}^{-2}(11.37 \pm 4.96) \mathrm{g}, 60$ individuals. $\mathrm{m}^{-2}(10.98 \pm 5.86) \mathrm{g}, 50$ individuals. $\mathrm{m}^{-2}(10.80 \pm 5.62) \mathrm{g}$, and 40 individuals.m-2 $(9.34 \pm 3.82) \mathrm{g}$. Results suggest that the rearing pond with an initial stocking density of 70 individuals. $\mathrm{m}^{-2}$ produced a better prawn final bodyweight compared to the other ponds, although the difference was not significant.

Prawn growth can also be measured based on Specific Growth Rate (SGR). The highest SGR during the 60 days culture period was obtained in the culture pond with 30 individuals. $\mathrm{m}^{-2}\left(2,569 \%\right.$.day $\left.{ }^{-1}\right)$, followed by 50 individuals. $\mathrm{m}^{-2}\left(2,105 \%\right.$.day $\left.^{-1}\right), 60$ individuals. $\mathrm{m}^{-2}\left(1,916 \%\right.$.day $\left.{ }^{-1}\right), 70$ individuals. $\mathrm{m}^{-2}\left(1,893 \%\right.$.day $\left.{ }^{-1}\right)$, and 40 individuals. $\mathrm{m}^{-2}\left(1,393 \%\right.$.day $\left.{ }^{-1}\right)$ (Table 1).

The same trend was observed in the mean body length of prawn measured every 10 days during the culture period. Mean body length of prawn increased with time in all treatments (Figure 4). The highest mean individual body length of $(10.70 \pm 1.50) \mathrm{cm}$ was measured in the rearing pond with 70 individuals. $\mathrm{m}^{2}$, followed by 30 individuals. $\mathrm{m}^{2}$ $(10.69 \pm 1.45) \mathrm{cm}, 60$ individuals. $\mathrm{m}^{2}(10.50 \pm 1.90) \mathrm{cm}, 50$ individuals. $\mathrm{m}^{2}(10.28 \pm 1.83) \mathrm{cm}$, and 40 individuals. $\mathrm{m}^{2}(9.86 \pm 1.33) \mathrm{cm}$.

Based on survival rate, the highest survival rate of $78.3 \%$ was documented from the pond with 30 individuals. $\mathrm{m}^{-2}$ stocking density, followed by 40 individuals. $\mathrm{m}^{-2}, 50$ individuals. $\mathrm{m}^{-2}, 60$ individuals. $\mathrm{m}^{-2}$ and 70 individual. $\mathrm{m}^{-2}$ stocking density with percentages of $76.3 \%, 70 \%, 70 \%$, and $67.1 \%$ respectively (Table 2 ). The performance of the developed system was higher in all stocking densities, compared to the system used by local farmer, where most of the SR was around 60\%, (Unpublished data).

In general, increasing the stocking density of prawns affected their growth rate and survival rate. The best growth rate was obtained in the culture initiated with 30 individuals. $\mathrm{m}^{-2}$ stocking density and decreased in line with the gradual increase of stocking density. Higher stocking density resulted in an increase of resources competition among the prawn, especially for space and feed, leading to cannibalism behaviour of the prawn due to the crowded effect. According to Satyani et al. [9], at higher stocking densities, prawn faces greater competition in acquring shelter as well as for food and locomotion space. In addition, higher density also causes an aggressive behavioural characteristic and increases cannibalism during moulting period due to stressful culture 
Citation: Suantika G, Astuti DI, Arief RR, Rusni M, Turendro OR (2012) Use of Zero Water Discharge Technology through the Application of Nitrifying Bacteria and Textile Vertical Substrate in Grow-Out Phase of Macrobrachium rosenbergii De Man. J Aquacult Res Dev 3:139 doi:10.4172/2155-9546.1000139

Page 4 of 6

conditions caused by the crowding effect. Since the main issues related to slow growth and low survival rates mainly concerns the limitation of territorial area and deterioration of water quality, the development and application of the zero water discharge contributes significantly in reducing those unexpected effects during the culture period, as indicated by the growth rate and survival rate that were not clearly different up to almost $130 \%$ stocking density compared to control (30 ind. $\left.\mathrm{mL}^{-1}\right)$ during the trial. By using the developed rearing technology, an extension of the substrate vertically as an addition to the horizontal substrate can be provided by means of a textile materialplaced vertically in the rearing ponds. Furthermore, the addition of nitrifying bacteria on a regular basis into the culture system also contributed tothe maintenance of ambient water quality parameters such as ammonium and nitrite levels at an acceptable level for prawn culture. According to Suantika [6], nitrifying bacteria has an important role in breaking down ammonium and nitrite into a less toxic inorganic soluble nitrogen substance, i.e., nitrate. The addition of $\mathrm{CaCO}_{3}$ powder as nitrifying substrate also contributed significantly to water quality, especially in buffering the stability of $\mathrm{pH}$ levels. Based on Suantika [10], $\mathrm{CaCO}_{3}$ applications in the rearing tanks enable the system to stabilize the $\mathrm{pH}$ level. Futhermore, $\mathrm{CaCO}_{3}$ also acts as a carbon source for the inoculated nitrifying bacteria. $\mathrm{CaCO}_{3}$ is also one of the limiting factors that regulates the moulting process of prawn, therefore it could enhance prawn growth [11]. From a biological perspective of culturing, the presence of a periphytic community at the textile vertical substrate in the rearing tanks also plays an important role in water quality purification, disease control, nutrient cycling, and food source for the prawn. The benefits of the periphytic community in prawn culture is well known because of its significant role in the microbial loop in ponds, especially in the nutrition cycle, feed sources, diseases control, and water purification [12]. All of the above contribute to better culture conditions for the prawn during grow-out period.

\section{Culture water quality}

Ammonium levels during the trial were still acceptable for prawn culture. Ammonium concentrations as low as 0.5 parts per million (ppm) is known to be a problem in cultures $[12,13]$. In general, ammonium level was lower during the early stages of the culture period and increased gradually to $0.09-0.12 \mathrm{ppm}$ in all treatments. The highest ammonium level of $0.123 \mathrm{ppm}$ was obtained in 60 individuals. $\mathrm{m}^{-2}$ stocking density, followed by 50 individuals. $\mathrm{m}^{-2}, 40$ individuals. $\mathrm{m}^{-2}, 70$ individuals. $\mathrm{m}^{-2}, 30$ individuals. $\mathrm{m}^{-2}$ stocking density: $0.116 \mathrm{ppm}, 0.101$ ppm, $0.092 \mathrm{ppm}$ and $0.089 \mathrm{ppm}$, respectively (Table 3).

Nitrite levels gradually decreased during the culture period,with relatively low levels. Overall, nitrite levels were still within the tolerance range for freshwater prawn culture. Macrobrachium rosenbergii has a tolerance for nitrite of up to $1 \mathrm{ppm}[6,13]$. The highest nitrite concentration was recorded at the beginning of culture period, measuring about $0.066 \mathrm{ppm}$ at the culture pond with 30 individuals. $\mathrm{m}^{-2}$ stocking density, followed by 50 individuals.m-2, 60 individuals. $\mathrm{m}^{-2}, 70$ individuals. $\mathrm{m}^{-2}$ and 40 individual. $\mathrm{m}^{-2}$ stocking density with the level of (0.066) ppm, (0.066) ppm, (0.065) ppm, and (0.064) ppm, respectively (Table 4).

Nitrate levels obtained during the culture period are presented in Table 5. Prawn can tolerate nitrate levels of up to $10 \mathrm{ppm}$ [14]. Nitrate levels tended to be stable and remained at the same level for all treatments during culture period. The highest nitrate level of 71.0 ppm was obtained in 60 individuals. $\mathrm{m}^{-2}$ stocking density, followed by 50 individuals. $\mathrm{m}^{-2}, 70$ individuals. $\mathrm{m}^{-2}, 30$ individuals. $\mathrm{m}^{-2}$ and 40 individuals. $\mathrm{m}^{-2}$ stocking density with the level of $62.9 \mathrm{ppm}, 56.6 \mathrm{ppm}$, $56.3 \mathrm{ppm}$ and 53,9 ppm, respectively (Table 5).

\begin{tabular}{|c|c|c|c|c|c|}
\hline \multirow{2}{*}{$\begin{array}{l}\text { Ammonium } \\
\text { level }\end{array}$} & \multicolumn{5}{|c|}{ Stocking density (individuals. $\mathrm{m}^{-2}$ ) } \\
\hline & 30 & 40 & 50 & 60 & 70 \\
\hline Highest (ppm) & 0.089 & 0.101 & 0.116 & 0.123 & 0.092 \\
\hline Lowest (ppm) & 0.044 & 0.045 & 0.044 & 0.042 & 0.044 \\
\hline $\begin{array}{l}\text { Beginning } \\
(\mathrm{ppm})\end{array}$ & 0.044 & 0.048 & 0.044 & 0.042 & 0.044 \\
\hline End (ppm) & 0.063 & 0.076 & 0.077 & 0.063 & 0.076 \\
\hline
\end{tabular}

Table 3: Ammonium level obtained at five different stocking densities during 60 days culture period.

\begin{tabular}{|l|l|l|l|l|l|}
\hline \multirow{2}{*}{ Nitrite Level } & \multicolumn{5}{|l|}{ Stocking density (individuals. $\mathrm{m}^{-2}$ ) } \\
\cline { 2 - 6 } & 30 & 40 & 50 & 60 & 70 \\
\hline $\begin{array}{l}\text { Highest } \\
\text { (ppm) }\end{array}$ & 0.066 & 0.064 & 0.066 & 0.066 & 0.065 \\
\hline $\begin{array}{l}\text { Lowest } \\
\text { (ppm) }\end{array}$ & 0.015 & 0.017 & 0.021 & 0.027 & 0.032 \\
\hline $\begin{array}{l}\text { Beginning } \\
\text { (ppm) }\end{array}$ & 0.066 & 0.064 & 0.066 & 0.066 & 0.065 \\
\hline End (ppm) & 0.024 & 0.031 & 0.033 & 0.045 & 0.034 \\
\hline
\end{tabular}

Table 4: Nitrite levels recorded at five different stocking densities during 60 days culture period.

\begin{tabular}{|l|l|l|l|l|l|}
\hline \multirow{2}{*}{ Nitrate Level } & \multicolumn{5}{|l|}{ Stocking density (individuals. $\mathrm{m}^{-2}$ ) } \\
\cline { 2 - 6 } & 30 & 40 & 50 & 60 & 70 \\
\hline Highest (ppm) & 56.3 & 54.0 & 63.0 & 71.0 & 56.6 \\
\hline Lowest (ppm) & 23.5 & 22.9 & 30.6 & 36.6 & 25.8 \\
\hline Beginning (ppm) & 51.7 & 45.1 & 46.0 & 46.0 & 50.0 \\
\hline End (ppm) & 27.7 & 33.9 & 44.3 & 46.8 & 30.6 \\
\hline
\end{tabular}

Table 5: Nitrate level obtained at five different stocking densities during 60 days culture period.

\begin{tabular}{|l|l|l|l|l|l|}
\hline DO Level & \multicolumn{6}{|l|}{ Stocking density (individuals. $\mathrm{m}^{-2}$ ) } \\
\cline { 2 - 6 } & 30 & 40 & 50 & 60 & 70 \\
\hline $\begin{array}{l}\text { Highest } \\
\text { (ppm) }\end{array}$ & 8.3 & 8.3 & 8.4 & 8.5 & 8.4 \\
\hline $\begin{array}{l}\text { Lowest } \\
\text { (ppm) }\end{array}$ & 5.6 & 5.15 & 5.2 & 4.3 & 3.7 \\
\hline $\begin{array}{l}\text { Beginning } \\
\text { (ppm) }\end{array}$ & 8.3 & 8.3 & 8.4 & 8.5 & 8.4 \\
\hline End(ppm) & 7.3 & 6.3 & 6.3 & 4.4 & 4.3 \\
\hline
\end{tabular}

Table 6: Dissolved oxygen (DO) levels obtained at five different stocking densities during 60 days culture period.

Dissolved oxygen levels during the trial was still acceptable for prawn culture. Dissolved oxygen levels tended to decrease gradually during the culture period,with the lowest DO level of $3.7 \mathrm{ppm}$ measured at the 60 individuals. $\mathrm{ml}^{-2}$ stocking density. At the end of the culture period (day 60), dissolved oxygen levels had decreased accordingly with the increase of stocking density (30 individuals. $\mathrm{m}^{-2}$ obtained $\sim 7.3$ ppm, 40 individuals. $\mathrm{m}^{-2} \sim 6.3 \mathrm{ppm}, 50$ individuals. $\mathrm{m}^{-2} \sim 6.3 \mathrm{ppm}, 60$ individuals. $\mathrm{m}^{-2} \sim 4.4 \mathrm{ppm}$, and 70 individuals. $\mathrm{m}^{-2} \sim 4.3 \mathrm{ppm}$ ) (Table 6).

The $\mathrm{pH}$ level recorded during trial was very stable and still within the tolerance range for prawn culture (Table 7). The range of $\mathrm{pH}$ was not significantly different among treatments, ranging between 7.71 7.96. After 60 days of culture period, the highest $\mathrm{pH}$ level was recorded in the culture with 50 individuals. $\mathrm{m}^{-2}$ stocking density, i.e., about 7.83 , followed by 40 individuals. $\mathrm{m}^{-2}, 30$ individual. $\mathrm{m}^{-2}, 60$ individual. $\mathrm{m}^{-2}$ and 70 individual. $\mathrm{m}^{-2}$ stocking density with the $\mathrm{pH}$ levels of 7.81, 7.72, 7.71 and 7.68 , respectively (Table 7 ).

From water quality measurement, it can be summarized that the use of biofiltration technology and textile vertical substrate in the zero water discharge rearing system enabled the culture to maintain a better 
Citation: Suantika G, Astuti DI, Arief RR, Rusni M, Turendro OR (2012) Use of Zero Water Discharge Technology through the Application of Nitrifying Bacteria and Textile Vertical Substrate in Grow-Out Phase of Macrobrachium rosenbergii De Man. J Aquacult Res Dev 3:139 doi:10.4172/2155-9546.1000139

Page 5 of 6

\begin{tabular}{|l|l|l|l|l|l|}
\hline \multirow{2}{*}{$\mathrm{pH}$ Level } & \multicolumn{5}{|l|}{ Stocking density (individuals. $\mathrm{m}^{-2}$ ) } \\
\cline { 2 - 6 } & 30 & 40 & 50 & 60 & 70 \\
\hline Highest & 8.42 & 8.15 & 7.91 & 7.95 & 7.96 \\
\hline Lowest & 6.74 & 6.74 & 6.31 & 6.42 & 6.52 \\
\hline Beginning & 7.74 & 7.87 & 7.91 & 7.95 & 7.96 \\
\hline End & 7.72 & 7.81 & 7.83 & 7.71 & 7.68 \\
\hline
\end{tabular}

Table 7: $\mathrm{pH}$ level obtained at five different stocking densities during 60 days culture period.

\begin{tabular}{|c|c|c|c|c|c|}
\hline \multirow[t]{2}{*}{ Parameters } & \multicolumn{5}{|c|}{ Treatment (Individual.m-2) } \\
\hline & 30 & 40 & 50 & 60 & 70 \\
\hline $\begin{array}{l}\text { Mean Body Weight } \\
\text { (g) }\end{array}$ & $\begin{array}{l}11.37 \pm \\
4.96\end{array}$ & $\begin{array}{l}9.34 \pm \\
3.82\end{array}$ & $10.80 \pm 5.62$ & $10.98 \pm 5.86$ & $11.46 \pm 4.517$ \\
\hline SGR (\% per day) & 2.569 & 1.393 & 2.105 & 1.916 & 1.893 \\
\hline Survival Rate (\%) & 78.3 & 76.3 & 70.0 & 70.0 & 67.1 \\
\hline Total Biomass (g) & 534.48 & 532.57 & 734.06 & 922.3 & 974.37 \\
\hline Total Feed $(\mathrm{g})$ & 526.75 & 625.87 & 864.49 & 1080.5 & 1334.14 \\
\hline $\begin{array}{l}\text { Feed Conversion } \\
\text { Ratio (FCR) }\end{array}$ & 0.99 & 1.18 & 1.18 & 1.17 & 1.37 \\
\hline Feed Cost/kg (Rp) & 9860 & 11750 & 11780 & 11720 & 13690 \\
\hline Seed Cost (Rp) & 15600 & 20800 & 26000 & 31200 & 36400 \\
\hline Total Income (Rp) & 27391 & 32545.24 & 44953.48 & 56186.00 & 69375.28 \\
\hline Profit (Rp) & 1931 & $-4,76$ & 7173.48 & 13266 & 19285.28 \\
\hline
\end{tabular}

Table 8: Estimated profit analysis of the prawn culture at five different stocking densities during 60 days culture period.

and more stable water quality during the culture period. The addition of nitrifying bacteria into the system as an agent of biofiltration contributed significantly in lowering and stabilizing the accumulation of ammonium and nitrite levels in the culture. The highest level of ammonium recorded during the trial was still within the tolerable range of the prawn culture. Freshwater prawn can tolerate a maximum ammonium ion in water at the level of $1 \mathrm{ppm}$, while in the form of ammonia, aquatic biota can only tolerate up to $0.1 \mathrm{ppm}$. In terms of nitrite levels, freshwater prawn can tolerate nitrite levels of up to 1 $\mathrm{ppm}$, however, it is often suggested to keep nitrite concentrations not to exceed $0.1 \mathrm{mg} / \mathrm{L}$ in cultivation. By using the biofiltration technology, nitrite concentration was kept low by the biofiltration mechanism of Nitrosomonas bacteria that changes nitrite into nitrate. Although not as toxic as ammonium, high nitrate levels can potentially cause death in cultivation areas. Whereas for nitrate, high concentration is relatively safe for aquatic biota because its toxicity is less than ammonium or nitrite. Furthermore, nitrate can also be used as a nutrient source for microalgae in rearing ponds. Generally during the culture period, ammonium, nitrite, and nitrate concentrations were maintained low and stable by means of the use of nitrifying bacteria.

Dissolved oxygen levels tended to decline in each treatment during 60 days of culture period because there was an increasing demand for dissolved oxygen due to the increase of prawn excretion, food residue, respiration and dead prawn. At the end of the culture period, dissolved oxygen levels at all treatments were never less than $4 \mathrm{ppm}$. Tolerance range of prawns to oxygen levels is between 3-7 mg/L [14]. Increasing the stocking density will result in lower dissolved oxygen levels. This could be explained because more individuals in the same volume will result in a higher oxygen demand for respiration in the culture [14].

Levels of $\mathrm{pH}$ tended to remain stable and within the prawn tolerance range of about 7-8.5 [14]. Stabilization of $\mathrm{pH}$ levels in culture can be maintained through the buffering process by $\mathrm{CaCO}_{3}$ that exist as biofilter substrate. The process was able to stabilize water acidification because of nitrification activity and accumulation of organic matter in the animal culture [6]. The addition of $\mathrm{CaCO}_{3}$ into bacterial growth media has an important role in continuously supplying $\mathrm{C}$ and creating an alkaline culture condition [15]. For prawns, the availability of $\mathrm{CaCO}$ in an acceptable level $\left(100 \mathrm{mg} . \mathrm{L}^{-1}\right)$ in the culture will increase the survival and growth rate up to $90 \%$ and $4.92 \pm 0.12 \mathrm{mg}$.day ${ }^{-1}$, respectively [11].

Temperature level $25^{\circ} \mathrm{C}$ in this experiment was relatively low compared to the optimum temperature for prawn, although still within the tolerance range of prawn juveniles, i.e., $25-30^{\circ} \mathrm{C}$ [14]. This low temperature could contribute to lowering growth rate because it may limit prawn metabolism capacity [14].

\section{Economic analysis}

In animal cultivation, several important parameters need to be considered in order to calculate the economic feasibility of rearing certain aquaculture commodities. Based on data collected from the experiment, a simple economic analysis to gain an idea of the profitability of the prawn rearing system at five different stocking densities was made based on several key parameters of the culture performance as illustrated in Table 8.

Note: the calculation made based on the dimension of $2 \mathrm{~m}^{2}$ of culture period.

From an economic perspective, the use of the zero water discharge rearing system resulted in high FCR and is profitable. The Feed Conversion Ratio (FCR) during the culture ranged between 0.99-1.37. The FCR increased in line with the increase of stocking density; however, the FCR level could still be compensated by the higher final harvest of the biomass. Even though FCR was higher at the highest stocking density, the highest profit of around Rp. 19.285 per $974 \mathrm{~g}$ was calculated for that highest stocking density $\left(70\right.$ ind. $\left.\mathrm{mL}^{-1}\right)$ because the survival rate of $67.1 \%$ is still acceptable for profit calculation of the system. Based on the above, the use of the developed rearing technology for prawn culture can improve the profit of the culture significantly and enable the farmer to improve productivity by increasing the animal density per $\mathrm{m}^{2}$ without any significant negative effect on the culture operational activities.

\section{Conclusion}

It could be concluded that the use of a zero water discharge system developed through the application of nitrifying bacteria and textile vertical substrate produced a significant positive effect for freshwater prawn (Macrobrachium rosenbergii (de Man)) culture, including higher and more consistent growth rate, survival rate, and total biomass production. In terms of water quality, the developed technology provides an acceptable culture condition for prawn culture. All of these advantages further contribute to higher efficiency of the rearing system, which consequently results in more profit to the prawn industry.

\section{Acknowledgments}

We would like to thank ITB Alumni Association (IA-ITB) for the financial support through HIBAH IKATAN ALUMNI 2010 - 2011 and The Fresh Water Prawn Seed Production Centre at Ciamis District for all the facilities and hospitality during the experiment.

\section{References}

1. Food and Agricultural Organization (FAO) (2010) World Review of Fisheries and Aquaculture.

2. Csavas I (1994) World Aquaculture Status and Outlook. Infofish International 5: 47-54.

3. New MB (2009) History and Global Status of Freshwater Prawn Farming. In: Freshwater Prawns Biology and Farming (eds. New MB, Valenti WC, Tidwel JH, D`Abramo LR, Kutty MN), Blackwell Publishing Ltd, UK, 1-9. 
Citation: Suantika G, Astuti DI, Arief RR, Rusni M, Turendro OR (2012) Use of Zero Water Discharge Technology through the Application of Nitrifying Bacteria and Textile Vertical Substrate in Grow-Out Phase of Macrobrachium rosenbergii De Man. J Aquacult Res Dev 3:139 doi:10.4172/2155-9546.1000139

4. Muir JF, Lombardi JV (2009) Grow Out Systems-Site Selection and Pond Construction. In: Freshwater Prawns Biology and Farming (eds. New MB, Valenti WC, Tidwell JH, D`Abramo LR, Kutty MN), Blackwell Publishing Ltd, UK.

5. Noerdjito DR, Suantika G (2006) Peningkatan Produktivitas Kultur Statis Branchionus Plicatilis Mueller, 1786 dengan Optimasi Jenis dan Konsentrasi Pakan Alami. J Biologi Indonesia 4: 9-18.

6. Suantika G, Astuti DI, Aditiawati P, Sasmita PG (2009) Development of ZeroWater Discharge Technology and Nitrifying Bacteria Application in Nursery Phase of the Giant Freshwater Prawn (Macrobrachium rosenbergii de Man), in: World Aquaculture Meeting Abstract Book, 208.

7. http://www.scribd.com/doc/9234254/Farming-Marine-Shrimp-in-RecirculatingFreshwater-Systems

8. Cappucino J, Sherman N (2011) Microbiology: A Labolatory Manual. NewYork: Benjamin Cummings.

9. Satyani D, Hadie LE, dan Dahlan, NM (1992) Pengaruh Berbagai Macam Pelindung dan Kepadatanterhadap Kelangsungan Hidup Pasca Larva Udang Galahdalam Penampungan. Bull Penel Perik Darat 11: 38-43.

10. Suantika G (2001) Development of a recirculation system for the mass culturing of the rotifer Brachionus plicatilis. Animal Production Department, Faculty of Agriculture and Applied Biological Sciences, Ghent University, Belgium.

11. Adhikaril S, Chaurasial VS, Naqvil AA, Pillail BR (2007) Survival and growth of Macrobrachium rosenbergii (de Man) juvenile in relation to calcium hardness and bicarbonate alkalinity. Turk J Fish Aquat Sci 7: 23-26.

12. Azim ME, Verdegem MC, J van Dam AA, Veveridge MCM (2005) Periphyton: ecology, exploitation and mangement, CABI Publishing, Wallingford, UK.

13. Mac Gibbon, Daniel J (2008) The effects of different water quality parameters on prawn (Macrobrachium rosenbergii de Man) yield, phytoplankton abundance and phytoplankton diversity at New Zealand prawns limited, Wairakel New Zealand. Master Thesis Victoria University of Wellington New Zealand.

14. Boyd C, Zimmermann S (2009) Grow-out systems-water quality and soil management. In: Freshwater Prawns: Biology and Farming (eds. New MB, Valenti WC, Tidwell JH, D’Abramo LR, Kutty MN), Blackwell Publishing Ltd, UK.

15. Wilton S, Morey R (2000) Biofilter Operating Procedurs, Resirc Today, PRAqua Technology Ltd., Praqua, 29. 